\title{
Notary Role in The Implementation of The Registration of Legal Services Through Integrated Electronic Based on PP No 24 of 2018
}

\author{
Mega Chandra Sera ${ }^{1}$, Tito Dwi Anggoro ${ }^{2}$ and Munsharif Abdul Chalim ${ }^{3}$
}

\begin{abstract}
Notary as the competent authority in the incorporation through Single Submission Online system is a system that integrates all licensing services sought under the authority of the Minister / Chairman of agency governors, regents / mayors made through electronics. The purpose of this study was to determine the role of notaries in the registration of legal entities through a single online submission as well as the challenges and solutions faced in the electronic registration of legal entities. The method used in the study of the approach in this paper is normative, the specification of this research is descriptive. Source data using secondary data. Data collection techniques using literature study or studies document. Data were analyzed using qualitative descriptive approach. The result of the conclusion of the first and second. The role of the Notary in Online registration single submission is in this case is a deed, the ratification of legal entities and registration of business entities through AHU / SABU and obstacles role of notaries in the registration of Online Single Submission in PP No. 24 in 2018 does not regulate the role of a notary for registration of legal entities the solution of these obstacles as a notary public officials are required to understand the process of incorporation through a single online submission in the form of service is not authorized

Keywords: Notary; Single Online Submission; A Legal Entity.
\end{abstract}

\section{Introduction}

Notary is a state official whose position is needed in the present. In modern times people no longer know the agreement is based on trust in each other as they once knew. Any agreement made society will inevitably lead to the notary as a means of validity in civil cases in the agreement. ${ }^{4}$ That is the position of the notary is very important in helping to create legal certainty for the public. Notaries are in the realm of prevention of legal issues through authentic deed he made as the most powerful evidence in court. ${ }^{5}$

Lies the significance of the notary profession is its main task as an authentic deed officials. Article 1870 Book of of Civil Law states that the authentic act provides absolute proof for parties manufacturer. Notary authorized by law to create the absolute evidentiary tool. This implies that the contents decided to authentic act was essentially considered correct. ${ }^{6}$ Act does not describe a business entity. During this term adopted legal entities of the term Netherlands (rechtpersoon), or the English term (legal persons), and there is also

\footnotetext{
${ }^{1}$ Students of Master Program (S2) in Notary Law Faculty of Law Universitas Islam Sultan Agung Semarang., email: mcsera7@gmail.com

2 Students of Master of Law, Faculty of Law, Universitas Islam Sultan Agung email sniperporjo@gmail.com

${ }^{3}$ Lecturer of Faculty of Law Universitas Islam Sultan Agung Semarang

${ }^{4}$ Gunardi \& Markus Gunawan. 2007, Kitab Undang-Undang Hukum Kenotariatan, PT Raja Grafindo, Jakarta, p. 16.

${ }^{5}$ Ibid.

${ }^{6}$ Ibid., P. 17.
} 
mentioned by the term persona moralist. Legal entities are subject to the same legal rights as a private man. ${ }^{7}$

R Subekti said legal entities primarily a legal entity or entities that can have rights, and acts like a man, and has a wealth of its own, can be sued or sue in front of a judge. Wirjono Prodjodikoro also noted the sense of a legal entity, namely the human body in addition to individuals who are considered to act within the law and who has the rights, obligations and legal nexus to other people or entities. ${ }^{8}$

Legal entities must perform the necessary registration to provide protection to companies that conduct their business honestly and openly, and guidance to businesses and companies, especially the economically weak groups. Person in the world of law is the subject of law or supporters of rights and obligations

Article 2 of Act No. 3 of 1982 regarding Company Registration Requirement contains:

"Companies aiming record informative materials that are made correctly from a company and a source of official information to all interested parties as to the identity, data, and other information on the company that is listed in the Company in order to ensure business certainty. "19

Currently the registration of legal entities has evolved into OSS (Online Single Submission) is a popular term Electronics as stipulated in Government Regulation No. 24 of 2018. The setting is in a government regulation has a high hierarchy, just under the Act so that all Presidential Regulation, regulation and so everything must bow and adjust the registration in the OSS system (single online submission)

Enrollment in the OSS system (single online submission) is a business communities, either individual or non-individual. In the case of non-individual businesses in the registration OSS systems (single online submission) must be accompanied by Deed and proof of the Decree of the Ministry of Justice and Human Rights. ${ }^{10}$

Based on the background mentioned above, the authors are interested in doing further research to be formulated in the form of research with the title: "Notary Role In The Implementation Of The Registration Of Legal Services Through Integrated Electronic Based On PP No 24 of 2018"

The problems outlined in this paper, namely, how the role of the Notary in the Implementation of Registration of Legal Entities through integrated services electronically or Online Single Submission according to Regulation No. 24 Of 2018 on Licensing Services Sought Integrated Electronic and What Obstacles and solutions of the role of the Notary against registration of legal entity through integrated services electronically or Online Single Submission.

\section{Research Methods}

This approach uses a juridic normative used to dig the law based on legislation or research literature. Specifications include a descriptive analytical study, which describes the legislation in force associated with legal theories and practice of positive law concerning the problem. Methods of data collection is by engineering literature through the stages of identification and inventory. The method of data analysis is to be analyzed using the

\footnotetext{
7 Mulhadi, 2017, Hukum Perusahaan Bentuk-bentuk Badan Usaha di Indonesia, Rajawali Pers, Jakarta, edition1, p 85-86

${ }^{8}$ Ibid., P. 20

${ }^{9}$ Act No. 3 of 1982 About the Company Registration Requirement.

${ }^{10}$ Government Regulation No. 24 of 2018 About Licensing Services Integrated Electronic Trying.
} 
iterative positive law theory and then deductively drawn the conclusion to answer the problem.

\section{Results and Discussion}

\subsection{The Role of the Notary Registration on Legal entities via Online Singles Submission}

Article 1 of Notary Law defines that Notary office as public official authorized to make an authentic deed and other authorities. The definition given by the office of the Notary Act refers to the duties and authority of being owned by the Notary as a public official has the authority to make an authentic deed as well as other authorities. A Notary, according to Tan Thong Kie is a functionary in the community, until now the office of a Notary is still respected. A Notary is usually regarded as an official where one can obtain advice may be unreliable. Everything that is written and specified (konstatir) is true, it is a powerful creator of a document in a legal process. ${ }^{11}$

According to Section 1868 Book of Civil Law mention that, "An authentic deed is a deed made in the form prescribed by law or before the competent public authority for it in the deed was made" 12

Made according to the form and manner set forth in UUJN. In addition to fulfilling the requirements prescribed in order for a certificate to be authentic, a Notary shall carry out their duties with full discipline, professional, and moral integrity should not be in doubt. Everything stated in the beginning and end of the deed is the responsibility of the Notary expression that reflects the state of the truth at the time of a deed.

According to Article 1 point 5 of Government Regulation No. 24 Of 2018 concerning integrated services electronically permission trying mention that:

"Trying Licensing Integrated Electronic or Online Single Submission hereinafter abbreviated as OSS is Trying Licensing issued by the agency OSS for and on behalf of the minister, the head of the institution, governor or regent / mayor to businesses through an integrated electronic system"13

OSS (single online submission) is OSS registration of legal entities in the form of Electronic document in accordance with the provisions of the legislation in the field of information and electronic transactions.

Legal entities are entities or associations are viewed as being subject to have the rights and perform legal acts such as humans. Bodies or associations that can have its own wealth. Participate in the traffic law through its coordinator, can be sued and sued in the face of the judge. Bodies or entities is called the Legal Entity (Rechtpersoon) which mean person (persoon) created by law. So there is a form of legal entity (rechtfiguur) is a legal entity (rechtpersoon) to have rights and obligations

Online single submission is trying to single licensing system in Indonesia aimed at facilitating business actors in conducting endeavor, particularly in obtaining legality attempted (Business License) to perform operational or commercial activity (operational or commercial licenses). To access the online system single submission, businesses must create an account (user id) and then by the account OSS able to process and license activities strive to businesses bas on Identification Number Trying (NIB), which was

\footnotetext{
${ }^{11}$ Tan Thong Kie, 2000, Studi Notariat Beberapa Mata Pelajaran dan Serba Serbi Praktek Notaris, Buku I, PT Icthiar Baru Van Hoeve, Jakarta, p. 157.

${ }^{12}$ Code of Civil law

${ }^{13}$ Government Regulation No. 24 of 2018 concerning Electronic Licensing Services Integrated basis.
} 
created by entrepreneur and declaration ability compliance commitment of affordable activity permit sought by businesses. Permission of business activities consist of location permits, environmental permits, building permits, certificate of acceptance function, and/or operating permits/commercial.

The role of the notary in this case is a deed, the ratification of legal entities and registration of business entities through AHU / SABU.

In this case OSS Deed requires complete with changes if any, and shall discount Enterprises TIN. OSS is self declare something that is input will be requested commitment. It is important that a valid license remains valid so it is not requested the OSS. ${ }^{14}$

OSS is a system for handling a variety of licensing seeks better terms for doing business, business licenses, as well as operational licenses when businesses started operation of its business and sell goods / services, both currently published by the central and local governments. OSS system connected to the national and local task force to facilitate business actors in the monitoring and escort licensing process sought. OSS system facilitates businesses in obtaining permits in a short time with the mechanism of fulfillment of commitments permit requirements.

OSS system facilitates both central and local government in the implementation of the licensing process attempted to process data collection, monitoring and acceleration of business. Every permission that is being taken care of and has not been issued by the ministries / agencies / local authorities and carried out before the system OSS issued then the business must take care of the permit back through the system OSS. Notaries in this case needs to be registering the legal entity through online for approval then have to apply to the Minister of Justice and Human Rights. Applicant is meant here is that every person either acting alone or with which direct provide power to the Notary to apply to the administration system of legal entities (SABH) which would then be registered through OSS. $^{15}$

The role of the Notary in the registration of legal entities OSS (singles online submission) as a public official makes Deed of Establishment of a legal entity shall have enough knowledge of the whole associated with business operations based on Law Company Limited has access to register Legalization of Incorporation to a system AHU Online, which automatically data will be connected with OSS systems (single online submission).

Notary with a role in the registration of legal entities through a single online submission included in the theory of the role or roles that theory role theory is ${ }^{16}$ :

"Theories that examine and analyze the role of institutions and public-institusi solve, resolve and put an end to the problems that arise in the life of society, nation and state"

Formal institution is an institution established officially by the state in carrying out roles in life berbangasa and state. Definition of role theory advanced by Mukti Fajar ND and Yulianto Achamd and focused on the role of the community to behave. Meanwhile, in the fact that not only the people who are asked to play a role, but the state, which in this case is represented by the government, the provincial government and district / city government, judiciary, and legislative and institutions that live and thrive in the community

\footnotetext{
${ }^{14}$ Albert R Aruan, 2018, Identifikasi Permasalahan OSS dalam Praktek Notaris dan Solusinya, PPT Pra Kongres \& pembekalan dan penyegaran pengetahuan, yogyakarta, 20 Oktober 2018, slide 13.

${ }^{15}$ Rina, Hambatan Notaris dalam pembuatan akta badan hukum perkumpulan, https://media.neliti.com/media/publications/164910-ID-hambatan-notaris-dalam-pembuatanakta-ba.pdf, p. 12

${ }^{16}$ Salim HS dan Erlies Septiana N, 2014, Penerapan Teori Hukum pada Penelitian Disertasi dan Tesis, Buku Kedua, Rajawali Pers, Jakarta,, p 142.
} 
as well as to act in accordance with his capacity to solve or put an end to the problems that arise over the role, need to be completed and perfected. ${ }^{17}$

\subsection{Obstacles and solutions role of notaries in the registration of legal entities via OSS}

Registration of legal entities, notary office to exercise his duties in relation to a deed of legal entities in accordance with the procedure OSS. According to Article 15 of Notary Law office Notary possible stating that the authority stipulated in other legislation. But until now there is no legal basis for Notaries in using OSS systems on Government Regulation No. 24 of 2018 regulates the licensing applicant and providers trying. On the one hand there is the role of stakeholders relating to the issuing of licenses sought, but in principle governing the issuing of licenses sought so that does not regulate the role of the Notary or Lawfirm. ${ }^{18}$ Notaries are obliged to understand and know the online registration of legal entities single submission, procedure, method and its mechanism. Notaries are required also to understand the changes related to the Articles of Association the company that made then ask Approval or registration to online AHU first after it had entered into an online system for processing as a single submission of new data or changes.

Notary in a single online registration form submission provides services to businesses for in Article 1 paragraph 4 of Government Regulation No. 24 of 2018 states that:

"Trying Licensing is registration granted to entrepreneurs to start and run a business and / or activities and are given in the form of approval set forth in the form of a letter / decision or fulfillment of the requirements and / or commitment"

Notary authority in the registration of legal entities, only to make deed, make changes to the articles of association, or endorsement to the ministry of law and human rights intents and purposes must comply with the Online single submission, so there is a match and permits can be published. therefore, the input data into a single online submission is not the authority of the Notary but businesses that established the authority of the enterprise. If there is one single input of the online registration submission is not the responsibility of the Public Notary for the legal relationship with the online Singles Submission not as a proxy, but only in the form of services. ${ }^{19}$

The theory used in the barriers and solutions of the role of notaries in the registration of legal entities through OSS is the theory of legal certainty, namely, rule of law is one of the objectives of the law. In achieving that goal served to divide the legal rights and obligations between individuals in society, dividing the authority that governs the way to solve the problem of law and to maintain legal certainty. The legal certainty the public will know the incidence rights and obligations under the law. Without the legal certainty that people will not understand what to do, do not know right or wrong actions, prohibited or not prohibited by law.

Legal purpose realistic approach is legal certainty and beneficial legal. The Positivism is more emphasis on the rule of law, while the functionalist priority to benefit the law, and if it can be argued that "summum ius summa injuria, summa lex, summa crux" which means

\footnotetext{
17 Ibid.

18 The Ministry of Economic Affairs and Coordinator of the Republic of Indonesia, Implementasi sistem OSS, Q\&a Seputar OSS, Jakarta, in August 2018, slides 17-18

19 Habib Adjie, Mencari Hubungan Hukum Notaris dan OSS,

https://m.facebook.com/story.php?story fbid=312373446255625\&id=100024489155226, accessed on October 8, 2018
} 
harsh laws that could hurt, but justice can help him, with thus eventhough justice is not a legal purpose only but the most substantive legal purpose is fair. ${ }^{20}$

\section{Closing}

\subsection{Conclusion}

Based on the research diterik following conclusion:

- The role of the Notary in the registration of legal entities OSS (singles online submission) as a public official makes Deed of Establishment of a legal entity shall have enough knowledge of the whole associated with business operations based on Law Company Limited has access to register Legalization of Incorporation to a system AHU Online, which automatically data will be connected with OSS systems (single online submission)

- Notary authorized to make the deed, make changes to the articles of association, as well as registering online AHU notary authority in a single online submission as a service

\subsection{Suggestion}

- Notary should be more careful in the registration of legal entities via OSS

- Necessary legal protection of the role of Notaries in the Legal Entity Registration in OSS to uphold the rule of law.

\section{Bibliography}

[1] Dominikus Rato. 2010. Filsafat Hukum Mencari Memahami Hukum Laksbang Presindo: Yogyakarta.

[2] Gunardi dan Markus Gunawan. 2007. Kitab Undang-Undang Hukum Kenotariatan. PT Raja Grafindo: Jakarta.

[3] Mulhadi. 2017. Hukum Perusahaan Bentuk-bentuk Badan Usaha di Indonesia. Edition 1 J Jakarta : Rajawali Pers

[4] Salim HS dan Erlies Septiana N. 2014. Penerapan Teori Hukum pada Penelitian Disertasi dan Tesis. Buku Kedua. Jakarta : Rajawali Pers

[5] Tan Thong Kie. 2000. Studi Notariat Beberapa Mata Pelajaran dan Serba Serbi Praktek Notaris. Buku I. Jakarta : PT Icthiar Baru Van Hoeve.

[6] Code of Civil law

[7] The Book of the Law of Commercial Law

[8] Act No. 2 of 2014 concerning Notary

[9] Law Decree No. 3 of 1982 regarding Company Registration Requirement

[10] Government Regulation No. 24 of 2018 on Licensing Services Integrated Electronic Sought

[11] Albert R Aruan. 2018. Identifikasi Permasalahan OSS dalam Praktek Notaris dan Solusinya, PPT

[12] Pra Kongres \& pembekalan dan penyegaran pengetahuan. Yogyakarta. 20 Oktober 2018.

[13] Habib Adjie. 2018 Mencari Hubungan Hukum Notaris dan OSS. https://m.facebook.com/story.php?story fbid=312373446255625\&id=10002448915 5226, diakses tanggal 8 Oktober 2018

\footnotetext{
${ }^{20}$ Dominikus Rato, 2010, Filsafat Hukum Mencari : Memahami Hukum, Laksbang Presindo, Yogyakarta, p. 59.
} 
Volume 5 Issue 4, December 2018

[14] Kementrian \& Koordinator Bidang Perekonomian Republik Indonesia. Implementasi sistem OSS Q \& A Seputar OSS. Jakarta. August 2018.

[15] Rina. Hambatan Notaris dalam pembuatan akta badan hukum perkumpulan, https://media.neliti.com/media/publications/164910-ID-hambatan-notaris-dalampembuatan-akta-ba.pdf. 